\title{
Synthesis of silver impregnated carbon nanotubes and cyclodextrin polyurethanes for the disinfection of water
}

\author{
LP Lukhele ${ }^{1}$, RWM Krause ${ }^{1 *}$, BB Mamba ${ }^{1}$ and MNB Momba ${ }^{2}$ \\ ${ }^{1}$ Department of Chemical Technology, University of Johannesburg, PO Box 17011, Doornfontein 2028, South Africa \\ ${ }^{2}$ The Department of Environmental, Water and Earth Sciences, Tshwane University of Technology, Arcadia Campus, \\ Private Bag X680, Pretoria 0001, South Africa
}

\begin{abstract}
Silver impregnated carbon nanotubes and cyclodextrin polymers were synthesised by first functionalising carbon nanotubes in a mixture of nitric and sulphuric acid before impregnating them with silver nanoparticles. The silver impregnated functionalised carbon nanotubes were then polymerised with $\beta$ cyclodextrin using hexamethylene diisocyanate as the linker. The polymers were characterised using various techniques. The polymers were then tested for their ability to destroy bacteria in water and were found to reduce bacterial cell counts in water spiked with E. coli (ATCC 25925) to as low as zero cfu/m $\ell$. Furthermore, the polymers could absorb $58 \%$ of para-nitrophenol from water spiked with this organic compound, which is a known pollutant in water.
\end{abstract}

Keywords: safe drinking water, bacteria, carbon nanotubes, cyclodextrins, nanoparticles

\section{Introduction}

Safe drinking water is one of mankind's most basic needs. The South African Constitution defines access to safe drinking water as a basic human right; therefore we cannot overemphasize the importance of access to safe drinking water for humans. Safe drinking water is defined as water that does not pose a health risk to consumers (Momba and Brouckaert, 2005). The World Health Organisation (WHO) defines safe drinking water as water that has chemical, microbial and physical characteristics that comply with both WHO and national standards. Bacterial contamination of water is a public health concern because it causes numerous diseases and some aesthetic problems such as malodour in water. Organisms such as Escherichia coli, Shigella spp., Salmonella spp., Vibrio spp., and Cryptosporidium are known to be transmitted by water and cause ill health in communities consuming water contaminated by bacteria.

Water treatment methods currently employed in South Africa have their drawbacks. Chlorine is the most widely used disinfectant (Genthe and Kfir, 1995), but chlorine reacts with water to form hypochlorous acid which in turn can react with natural organic matter (NOM) such as humic acid and fulvic acid to form disinfection by-products (DBPs). These byproducts include trihalomethanes (THMs), polychlorinated biphenyls (PCBs) and other halogenated hydrocarbons (Genthe and Kfir, 1995). Some of these halo-hydrocarbons are known carcinogens and endocrine disruptors and are difficult to remove from water. Also, the detection of organics, microorganisms and other pollutants in distribution systems have proven that there is a need for the introduction of better water treatment methods that will ensure that water supplied to communities is of high quality (Schutte and Focke, 2007).

\footnotetext{
* To whom all correspondence should be addressed.

용 +27(11) 559 6152; fax: +27(11) 5596425 ;

e-mail: rkrause@uj.ac.za

Received 4 February 2010; accepted in revised form 31 May 2010.
}

Silver has a long history of use in medicine as antimicrobial agents (Yoon et al., 2007). Ancient Egyptians used silver vessels to keep wine, water and vinegar for purification (Shashikala et al., 2007). The antimicrobial activity of silver ions involves their interaction with the -SH group in bacterial enzymes (Wilks et al., 2005) and produces structural changes to the cell membranes of bacteria (Alcamo, 2001). Studies conducted on bacterial cells exposed to silver showed cell damage consistent with cell membrane damage (Brook et al., 2007). Silver deposited on carbon surfaces has been proven to have strong antibacterial action. Electrodeposited silver on activated carbon was shown to reduce viable bacteria in water by up to $7 \log$ (Ibarra et al., 2007).

Carbon nanotubes and cyclodextrin polymers synthesised in our laboratories have the capability to remove organic pollutants from water (Salipira et al., 2007). The aim of this study was to prepare dual functional polymers to remove organic pollutants from water and destroy bacteria. This was done by impregnating the polymers with the antimicrobial metal, silver.

\section{Methods}

\section{Functionalisation of multiwalled carbon nanotubes (MWNT)}

Multiwalled CNTs ( $1 \mathrm{~g})$ from Sunnano ${ }^{\mathrm{TM}}$ were oxidised using a mixture $(40 \mathrm{~m} \ell)$ of nitric acid $\left(\mathrm{HNO}_{3}\right)$ and sulphuric acid $\left(\mathrm{H}_{2} \mathrm{SO}_{4}\right)$ at a 1:3 ratio for $30 \mathrm{~min}$ to incorporate carboxyl $(-\mathrm{COOH})$ and hydroxyl $(-\mathrm{OH})$ groups onto the MWNT. The mixture was then diluted with distilled water and filtered using a PTFE filter membrane $(0.47 \mu \mathrm{m})$. The MWNTs were dried in a desiccator at room temperature overnight and characterised using FT-IR spectroscopy.

\section{Synthesis of silver nanoparticles on functionalised MWNTs}

Aqueous solutions containing $\mathrm{AgNO}_{3},(0.01 \mathrm{M})$ polyvinylpyrrolidone (PVP) $(20 \mathrm{mM})$ and ethanol were stirred at $50^{\circ} \mathrm{C}$ for $2 \mathrm{~h}$ 
(Dai et al., 2007). The functionalised MWNTs were immersed in the aqueous solution, after which ascorbic acid ( $3.5 \mathrm{~g})$ was added to the mixture which was then stirred for a further $2 \mathrm{~h}$ (Wang et al., 2006a). The Ag-MWNT composites were then filtered, washed with double-distilled water $(1 \ell)$ and dried in an oven at $150^{\circ} \mathrm{C}$ for $3 \mathrm{~h}$. Characterisation of the silver nanotubes was done using IR spectroscopy to test for the presence of the $-\mathrm{COOH}$ and $-\mathrm{OH}$ groups required for polymerisation. Transmission electron microscopy (TEM) was used to confirm whether the silver nanoparticles had been loaded onto the functionalised MWNTs.

\section{Polymerisation of silver MWNTs onto cyclodextrin polymers}

Ag-MWNTs $(0.04 \mathrm{~g})$ were sonicated in dimethyl formamide (DMF) $(2 \mathrm{~m} \ell)$ for $15 \mathrm{~min}$. $\beta$-cyclodextrin (CD) $(4 \mathrm{~g})$ was dissolved in DMF $(40 \mathrm{~m} \ell)$ in a round-bottom flask. The Ag-MWNTs $(0.04 \mathrm{~g})$ in DMF were then added and the mixture was stirred at $70^{\circ} \mathrm{C}$. Hexamethylene diisocyanate (HMDI) $(4 \mathrm{~m} \ell)$ was added drop-wise and the reaction was stirred for $24 \mathrm{~h}$ under inert conditions. The progress of the reaction was monitored using IR to check for the disappearance of the isocyanate (NCO) peak at $2700 \mathrm{~cm}^{-1}$. The absence of the NCO peak at the end of the reaction was an indication of the completion of the reaction. The polymer (Ag-MWNT-CD) was precipitated using acetone and dried under vacuum. A grey powdery product was obtained (Salipira et al., 2007).

Other polymers containing no-silver but only the MWNTs (1\% MWNT-CD), and a polyurethane containing only the CD ( $\mathrm{CD}(\mathrm{HMDI})$ ), were also synthesised by the same procedure in order to compare the efficacy of all the polymers.

\section{Antibacterial application}

1\% MWNT-CD (0.03 g) and Ag-MWNT-CD (0.03 g), and $\mathrm{CD}$ (HMDI) (0.03 g) polymers were packed in empty SolidPhase-Extraction (SPE) cartridges. The cartridges were sterilised by autoclaving. E. coli (ATCC 25925) cells were grown in nutrient broth (Merck) for $24 \mathrm{~h}$ and incubated at $37^{\circ} \mathrm{C}$ while shaking. The $E$. coli cells were washed several times using phosphate-buffered solution (PBS) and were re-suspended in $10 \mathrm{~m} \ell$ of $0.01 \mathrm{M}$ tetrasodium pyrophosphate. The $10 \mathrm{~m} \ell$ of cells suspended in $10 \mathrm{~m} \ell$ tetrasodium pyrophosphate was then added to $990 \mathrm{~m} \ell$ of sterile distilled water and mixed well. The concentration of $E$. coli-spiked water was established by serially diluting the water then culturing on nutrient agar plates for $24 \mathrm{~h}$ at $37^{\circ} \mathrm{C}$. The spiked water was passed through the cartridges packed with the polymers. The cartridges were connected to a separating funnel, which carried the spiked water, and a collection flask. Flow rate was adjusted to $5 \mathrm{~m} \ell / 15 \mathrm{~min}$ for $90 \mathrm{~min}$. Funnels had been sterilised by soaking in $5 \%$ bleach solution and rinsed using sodium thiosulphate, while the flasks were sterilised by autoclaving.

Water samples were cultured on Chromocult media (Merck) using spread plate and membrane filter methods. Serial dilutions where necessary were done using sterile saline solution. E. coli grows on Chromocult media to form violet colonies. The bacterial cell count was done using the colony count method. The efficiency of the polymers in destroying bacteria was evaluated by comparing the initial and final bacterial count after passing the spiked water through polymer-packed cartridges.

\section{Removal of para-nitrophenol (PNP)}

The polymers were further tested for their ability to remove a model organic pollutant in spiked water with a concentration of $10 \mu \mathrm{g} / \mathrm{g}$. The polymers $(0.03 \mathrm{~g})$ were packed in separate SPE cartridges and $30 \mathrm{~m} \ell$ of the spiked water was passed through the polymer. The resultant filtrate was analysed using ultraviolet (UV) spectroscopy. The PNP absorption maximum is at $318 \mathrm{~nm}$ hence all absorbance readings were read at $318 \mathrm{~nm}$.

\section{Nanoparticle leaching studies}

Silver-impregnated carbon nanotubes and cyclodextrin polymers were packed in SPE cartridges and were connected to the disinfection set-up. Distilled water $(100 \mathrm{~m} \ell)$ was passed through the polymers at flow rates of 5,30 and $85 \mathrm{~m} \ell / \mathrm{min}$. The eluted water was then analysed for the presence of leachedout silver using atomic absorption spectroscopy (Ibarra et al., 2007).

\section{Results and discussion}

\section{Functionalisation of MWNT}

Oxidation of the multiwalled carbon nanotubes was successfully accomplished, forming functionalised-MWNT (f-MWNTs), as confirmed by IR spectroscopy. The presence of groups such as the carbonyl peak at $1730 \mathrm{~cm}^{-1}$ and the hydroxyl peak at $3437 \mathrm{~cm}^{-1}$ confirms the functionalisation of the MWNT. In addition, the f-MWNTs were also soluble in water, while as-synthesised MWNTs are not. This can be attributed to the presence of the $-\mathrm{COOH}$ and $-\mathrm{OH}$ groups on the surfaces of the f-MWNTs. The oxygen-containing groups also provide active sites that improve the reactivity the MWNTs. These sites also make it possible to load silver nanoparticles on the surfaces of the MWNTs.

\section{Silver nanoparticle impregnation}

The synthesis of silver and copper nanoparticles using ascorbic acid as a reducing agent in the presence of polyvinylpyrrolidone, as surfactant, and silver nitrate solution at $0.01 \mathrm{M}$ yielded particles that are nano-sized according to the transmission electron microscopy image (Fig. 1) This figure shows the loading of the nanoparticles onto the f-MWNT with a diameter range of 10 to $30 \mathrm{~nm}$. A weak reducing agent like ascorbic acid

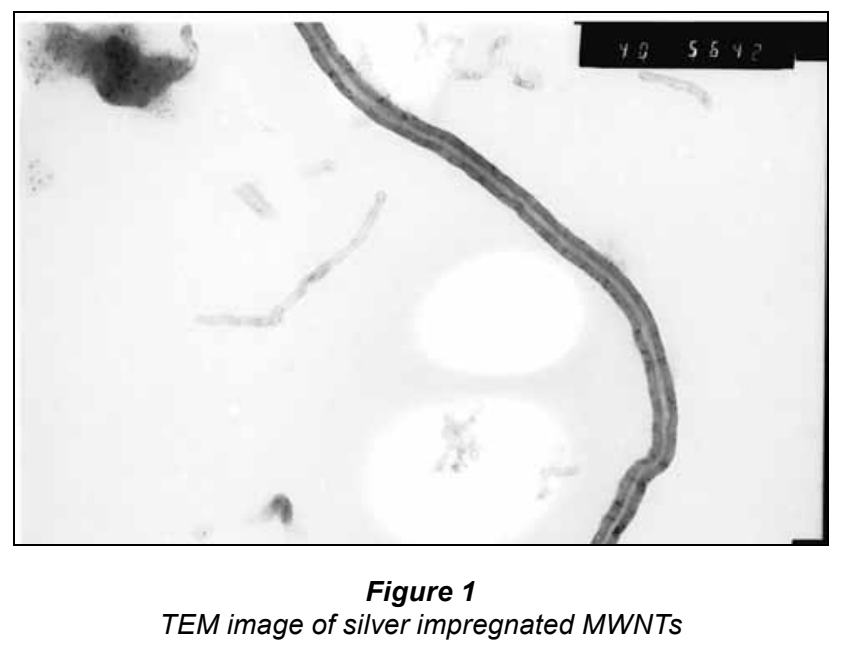

Available on website http://www.wrc.org.za ISSN 0378-4738 (Print) = Water SA Vol. 36 No. 4 July 2010 ISSN 1816-7950 (On-line) = Water SA Vol. 36 No. 4 July 2010 


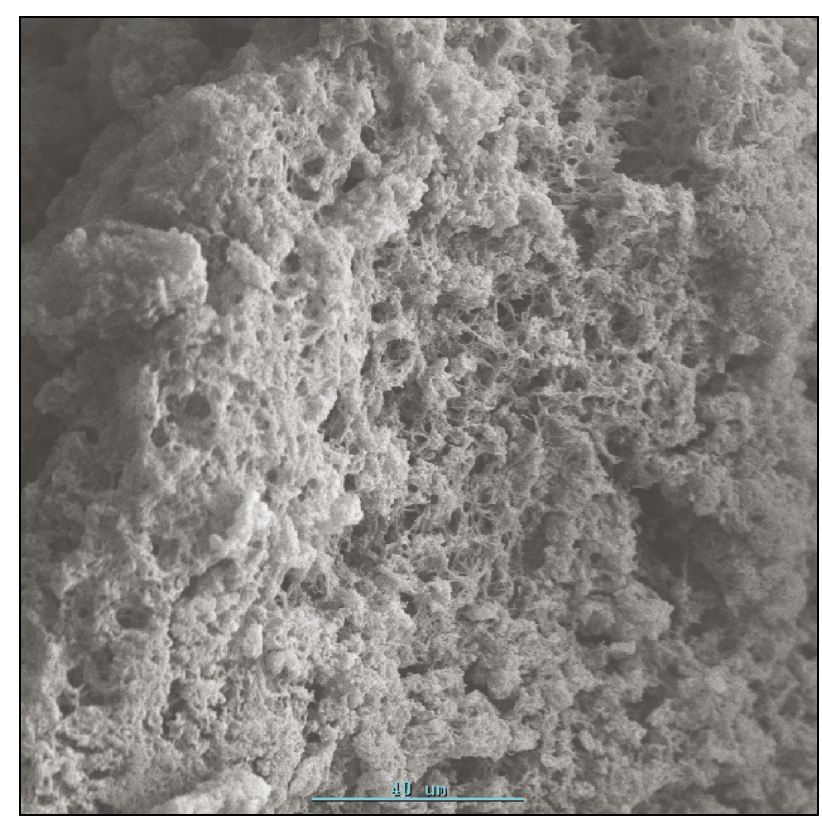

Figure 2

SEM image of Ag-MWNT-CD polymer

yields particles ranging from 1 to $10 \mathrm{~nm}$ when synthesised in PVP (Wang et al., 2006b). From the TEM image, the presence of dark spots on the outer wall of the carbon nanotubes suggests successful impregnation of silver nanoparticles into f-MWNTs, and was confirmed by EDS analysis.

\section{Synthesis of silver MWNT-CD polymer}

The synthesis of the Ag-MWNT-CD polymers was successful. The disappearance of the NCO peak in the IR spectrum marked the completion of the reaction. The polymers were characterised using scanning electron microscopy (SEM) (Fig. 2) and other techniques to determine the surface properties of the polymers. The polymers were found to have a spongy appearance.

\section{Antibacterial testing}

Monitoring of water quality for microbial parameters requires the selection and use of indicator organisms. The coliform groups, total and faecal coliforms, are most widely used as indicator organisms, particularly of faecal contamination of water. Escherichia. coli, which is classified under faecal coliforms, has been used worldwide as a specific indicator of bacterial contamination in drinking water. It has also been used for similar research projects to this one (Momba et al., 2003).

The initial count of the spiked water used was found to be $1.3 \cdot 10^{7} \mathrm{cfu} / \mathrm{m} \ell$. Table 1 shows the resultant counts after passing the spiked water through the polymers.

\begin{tabular}{|l|c|c|c|}
\hline \multicolumn{4}{|c|}{$\begin{array}{c}\text { Table } \mathbf{1} \\
\text { Table of per cent destruction of bacteria after } \\
\text { filtering through various polymers }\end{array}$} \\
\hline \multirow{2}{*}{\begin{tabular}{l|c|c|} 
Polymer \\
\cline { 2 - 4 }
\end{tabular}} & $\mathbf{3 0}$ & $\mathbf{6 0}$ & $\mathbf{9 0}$ \\
\hline CD-(HMDI) & 72 & 70 & 48 \\
\hline MWNT-CD & 84 & 48 & 45 \\
\hline Ag-MWNT-CD & 94 & 95 & 100 \\
\hline
\end{tabular}

From the results shown in Table 1, two trends can be noted. One is that the amount of bacteria which is destroyed by the Ag-CNT-CD polymer increases with time. The second trend is the decrease in the removal of bacteria with time. The $\mathrm{Ag}$ MWNT CD showed an initial removal of $94 \%$ within the first $30 \mathrm{~min}$ of the testing period. After $90 \mathrm{~min}$ a $100 \%$ removal of bacteria by the silver polymers was observed. No amount of washing of the polymer was able to 'dislodge' viable bacteria from the polymer. With increased contact time the silver-impregnated polymers had an improved antibacterial characteristic. With regards to the polymers that did not contain silver nanoparticles, there was a sharp fall in the removal of bacteria over time. The removal by MWNT CD polymer shows a drop from $84 \%$ to $48 \%$, whilst bacteria removal by cyclodextrin(HMDI) polymers decreases from $71 \%$ to $48 \%$. The limited removal of bacteria by the metal-free polymers can be attributed to the bacteriostatic properties of carbon surfaces (Park and Jang, 2003). Activated carbon, for example, exhibits a limited bacteriostatic property (Oya and Yoshida, 1995). However, the mode of the bacteriacarbon surface interaction is not known. The phenomenon of antibacterial properties of the silver can be explained by the fact that the metal nanoparticles carry a positive charge which is opposite to the negative charge on the gram negative cell wall of E. coli, thus producing structural changes on the bacterial cell membranes (Zhang et al., 2004).

\section{Removal of para-nitrophenol}

The removal of PNP by the silver-loaded polymers was quite low when compared with that of the carbon nanotube and cyclodextrin polymers, and that of native cyclodextrin polymers. Also it is apparent from BET analysis that the silverimpregnated polymers had a low surface area when compared with the silver-free polymers. Silver impregnation of the polymers has a negative effect on the surface area of the polymers. Silver loading also compromises the polymer's ability to remove organics from water.

\begin{tabular}{|l|c|c|c|}
\hline Polymer & $\begin{array}{c}\text { CD } \\
\text { (HMDI) }\end{array}$ & CNT CD & $\begin{array}{c}\text { Ag CNT } \\
\text { CD }\end{array}$ \\
\hline \% absorption (removal) & 62 & 88 & 52 \\
\hline Surface area $\left(\mathbf{m}^{\mathbf{2}} / \mathbf{g}\right)$ & 1.72 & 5.72 & 0.78 \\
\hline
\end{tabular}

\section{Silver leaching-out studies}

Some concerns have been raised regarding the toxicity of engineered nanomaterials towards the environment and humans. In this study, it was necessary to assess the leachability of silver nanoparticles into the water treated with the silver polymers. Treated water was found to contain less than $0.1 \mathrm{mg} / \ell$ of silver; silver levels in treated water were below the instrument's detection limit. According to the World Health Organisation's Water Quality Guidelines for Drinking Water, silver levels of $0.1 \mathrm{mg} / \ell$ could be tolerated without any health risk. This concentration gives a total dose over 70 years of half the human NOAEL (no observed adverse effect level) of $10 \mathrm{~g}$ (WHO, 2006). Hence possible leaching of silver into the water when using silverimpregnated polymers does not pose any significant health risk since levels are below $0.1 \mathrm{mg} / \ell$.

\section{Conclusion}

The synthesis of silver impregnated polymers was achieved and was confirmed using various characterisation techniques. The 
silver-loaded polymers displayed an improved ability to destroy bacteria in water when compared to the native carbon nanotube and cyclodextrin polymer and the cyclodextrin polymer. From the results, it can be concluded that metal loading does improve the antibacterial properties of the polymers and can be used as an alternative disinfection material.

In the removal of organics from water, the metal-loaded polymers do not perform as well as the native carbon nanotubes and cyclodextrin polymers. It appears that there is a relation between the adsorption of organics and the surface area of the polymers but no concrete conclusions can be drawn at this stage.

\section{Acknowledgements}

Funding from National Research Foundation, Nanotechnology Innovation Centre, Centre of Excellence in Strong Materials and the University of Johannesburg is gratefully acknowledged.

\section{References}

ALCAMO IE (2001) Fundamentals of Microbiology. Jones and Bartlett Publishers, Inc., London.

BROOK LA, EVANS P, FOSTER HA, PEMBLE ME, STEELE A, SHEEL DW and YATES HM (2007) Highly bioactive silver and silver/titania composite films grown by chemical vapour deposition. J. Photochem. Photobiol. 187 (1) 53-63.

DAI K, SHI L, FANG J and ZHANG Y (2007) Synthesis of silver nanoparticles on functional multi-walled carbon nanotubes. Mater. Sci. Eng. 465 283-286.

GENTHE B and KFIR R (1995) Studies on Microbiological Drinking Water Quality Guidelines. WRC Report No. 469/1/95. Water Research Commission, Pretoria, South Africa.

IBARRA H, CASILLAS N, SOTO V, SOTO M, VITELA R and SALAZAR SG (2007) Surface characterisation of electrodeposited silver on activated carbon for bacterial purposes. J. Colloid Interface Sci. 314 562-571.

MOMBA MNB and BROUCKAERT BM (2005) Guidelines for Ensuring Sustainable Effective Disinfection in Small Water Supply Systems. WRC Report No. TT 249/05. Water Research Commission, Pretoria, South Africa.
MOMBA MNB, MALAKATI VK and THERONE J (2003) Abundance of pathogenic Escherichia coli, Salmonella typhemurium and Vibrio cholerae in Nkonkobe drinking water sources. $J$. Water Health 4 289-296.

OYA A and YOSHIDA S (1995) Preparation and properties of an antibacterial activated carbon fibre containing mesopores. Carbon 34 53-57.

PARK S and JANG Y (2003) Preparation and characterisation of activated carbon fibres supported with silver metal for antibacterial behaviour. J. Colloid Interface Sci. 261 238-243.

SALIPIRA KL, MAMBA BB, KRAUSE RWM, MALEFETSE TJ and DURBACH SH (2007) Carbon nanotubes and cyclodextrin polymers for removing organic pollutants from water. Environ. Chem. Lett. 5 13-17.

SCHUTTE CF and FOCKE W (2007) Evaluation of Nanotechnology for Application in Water and Wastewater Treatment and Related Aspects in South Africa. WRC Report No. KV 195/07. Water Research Commission, Pretoria, South Africa.

SHASHIKALA V, KUMAR VS, PADMASRI AH, RAJU BD, MOHAN SV, SARMA PN and RAMA RAO KS (2007) Advantages of nano-silver-carbon covered alumina catalyst prepared by electro-chemical method for drinking water purification. J. Mol. Catal. 268 95-100.

WANG JX, WEN L, WANG Z and CHEN J (2006a) Immobilisation of silver on hollow silica nanospheres and nanotubes and their antibacterial effects. Mater. Chem. Phys. 96 90-97.

WANG AL, YIN HB, REN M, CHENG XN, ZHOU QF and ZHANG $\mathrm{XF}$ (2006b) Effects of different functional group-containing organics on morphology-controlled synthesis of silver nanoparticles at room temperature. Acta Metallurgica Sinica (English Letters) 19 $362-370$.

WHO (2006) Guidelines for Drinking Water Quality ( $3^{\text {rd }}$ edn.). World Health Organisation, Geneva.

WILKS SA, MICHELS H and KEEVIL CW (2005) The survival of Escherichia coli 0157 on a range of metal surfaces. Int. J. Food Microbiol. 105 445-454.

YOON K, BYEON J, PARL J and HWANG J (2007) Susceptibility constants of Escherichia coli and Bacillus subtilis to silver and copper nanoparticles. Sci. Total Environ. 373 572-575.

ZHANG S, FU R, WU D, XU W, YE Q and CHEN Z (2004) Preparation and characterisation of antibacterial silver dispersed activated carbon aerogels. Carbon 42 3209-3219. 